\title{
Soil Macrofauna Behaviour in the Presence of Pesticides and Organic Amendments
}

\author{
Rayim Wendé Alice Nare1, Paul Windinpsidi Savadogo², Mamoudou Traore², André Gountan ${ }^{3}$, \\ Hassan Bismarck Nacro ${ }^{3}$, Michel Papaoba Sedogo ${ }^{2}$ \\ ${ }^{1}$ Département des Substances Naturelles, Institut de Recherche en Sciences Appliquées et Technologies (IRSAT), Ouagadougou, \\ Burkina Faso \\ ${ }^{2}$ Laboratoire Sol-Eau-Plante, Institut de l'Environnement et de Recherches Agricoles (INERA), Ouagadougou, Burkina Faso \\ ${ }^{3}$ Laboratoire d'Etude et de Recherche sur la Fertilité des Sols (LERF), Université Polytechnique de Bobo Dioulasso (UPB), Bobo \\ Dioulasso, Burkina Faso \\ Email: alice.nare@gmail.com, paul.savadogo@gmail.com, tramadalbela@yahoo.fr, gountandre@yahoo.fr, nacrohb@yahoo.fr, \\ michel_sedogo@yahoo.fr
}

How to cite this paper: Nare, R.W.A., Savadogo, P.W., Traore, M., Gountan, A., Nacro, H.B. and Sedogo, M.P. (2017) Soil Macrofauna Behaviour in the Presence of Pesticides and Organic Amendments. Journal of Geoscience and Environment Protection, 5, 202-212.

https://doi.org/10.4236/gep.2017.53014

Received: January 10, 2017

Accepted: March 26, 2017

Published: March 29, 2017

Copyright $\odot 2017$ by authors and Scientific Research Publishing Inc. This work is licensed under the Creative Commons Attribution International License (CC BY 4.0).

http://creativecommons.org/licenses/by/4.0/

\begin{abstract}
Insects attack vegetable crop, leading to an overuse of pesticides. Organic amendments are recommended to increase soil fertility. The impact of two insecticides, on soil macrofauna under rainfed cultivation of tomato (Lycopersicon esculentum L.) with or without organic amendments was evaluated. The insecticides were Lambda Super (lambda-cyhalothrin) and Dursban (chlorpyrifos ethyl) and organic amendments were compost, pig manure and cattle manure. An experimental device in split-plot with three replicate was installed. Pesticides were applied periodically each week during the experiment. The results have showed that with organic amendments, Lambda super increased the earthworm population compared to the control. Indeed, we found 42 individuals $/ \mathrm{m}^{2}$ with compost; 1 individuals $/ \mathrm{m}^{2}$ with pig manure and 27 individuals $/ \mathrm{m}^{2}$ with cattle manure but the control was 0 individuals $/ \mathrm{m}^{2}$ in the presence of Lambda super without organic amendment. Similarly, Dursban increased the population of earthworms in the presence of organic amendment with 11,37 and 91 individuals $/ \mathrm{m}^{2}$ respectively for compost, pig manure and cattle manure. Lambda super with compost has led to a total elimination of termites. In the presence of Dursban, a decrease in the number of termites was observed when adding cattle manure (11 individuals $\left./ \mathrm{m}^{2}\right)$ compared to the control containing only Dursban $\left(21\right.$ individuals $\left./ \mathrm{m}^{2}\right)$. Better distribution of macrofauna was obtained with treatment with Dursban and compost $(\mathrm{E}=0.99$ for earthworms and $\mathrm{E}=0.96$ for termites). All organic amendments used in our study stimulated earthworm population, but more in the presence of Lambda super or Dursban.
\end{abstract}




\section{Keywords}

Pesticides, Organic Amendment, Soil Macrofauna, Burkina Faso

\section{Introduction}

Tomato (Solanumly copersicum L.) is grown all over the world, and is an important part of the diet. Tomato is the main vegetable in Burkina Faso [1], and is cultivated on 9529.23 ha (2010/2011 season). However this vegetable is very vulnerable to pest attacks. Among the tomato's pest we have Tetranychus urticae Koch, Helicoverpa armigera Hübner and Bemisia tabacci. The attack of them promotes the use of pesticides by farmers in vegetable production in Burkina Faso. Among the formulations, there is the Lambda super $2.5 \mathrm{EC}$ with lambdacyhalothrin as the active ingredient and Dursban $4 \mathrm{E}$ with chlorpyrifosethyl as the active ingredient. These insecticides fight efficiently against plant pests, especially in vegetable gardens. However, besides the benefit of the use of pesticides for agricultural production, it is crucial to worry about the environment pollution and the impacts on human and animal health [2]. Chlorpyrifos ethyl is an active substance which remains in the top $(0-10 \mathrm{~cm})$ soil horizon [3]. Its metabolites are more toxic than the parent compound and have negative effects on animal health and soil microbial activities [4]. Regarding lambda-cyhalothrin, Förster et al. [5] showed that the effects on soil macrofauna depend on the macrofauna group and the environmental conditions such as temperature and humidity.

In Burkina Faso, organic amendments are recommended by the government for soil fertility management. Some studies from [6] and [7] showed that organic amendments have a positive effect on the maintenance and proliferation of landbased flora. Ouédraogo et al. [6] showed that the contribution of organic matter provided by crop residues has increased the number of termites.

However, there is a lack of information on the contribution of organic amendments to reduce the effects of pesticides on soil non-target macrofauna. The objective of this study is to evaluate the effects of pesticides used in vegetable production on soil macrofauna in the presence of organic amendment. This is in order to find some recommendable organic amendments for farmers to reduce the impact of pesticides on soil fertility. We issued the following assumptions: 1) organic amendments, in the presence of functional groups and a wide variety of microorganisms are able to retain and stimulate the degradation of pesticides in soil and reduce their impact on soil macrofauna; 2) the ability to reduce the effect of pesticides on soil macrofauna depends on the organic amendments used.

\section{Materials and Methods}

\subsection{The Study Site}

The study was conducted in the rainy season at Kamboinsé $\left(12^{\circ} 28^{\prime} \mathrm{N}, 1^{\circ} 32^{\prime} \mathrm{W}\right.$, 
$296 \mathrm{~m}$ above sea level) in 2013 in northern Burkina Faso located in the Soudanian climatic zone with a mean temperature of $27^{\circ} \mathrm{C}$. The site was chosen to get the same type of soil and to work in intense pest invasion area.

The rainy season is from June to September with an average rainfall of 1000 mm per year. The study has been conducted for 130 days. The soils of Kamboinsé area are mostly ferruginous leached, based on the deep sandy material, hydromorphic soils with little humus pseudogley inherited in association with lithosols on ironstone [8]. The physical and chemical characteristics of the soil (0 $-20 \mathrm{~cm}$ ) are shown in Table 1.

\subsection{Experimental Design}

A split plot design with three replications was laid out. The main treatment was the use of insecticides. Lambda super 2.5 EC (25 g/l lambda-cyhalothrin) applied at the recommended rate $(600 \mathrm{ml} / \mathrm{ha})$; and Dursban $4 \mathrm{E}$ (480 g/l of Chlorpyrifosethyl) applied at the recommended rate $(1.25 \mathrm{l} / \mathrm{ha})$. The pesticides were applied three times during the tomato growth cycle (130 days). The first applied was 21 days after the experiment set up and 10 days after each application. The plots were $3 \mathrm{~m} \times 10 \mathrm{~m}$ and $1 \mathrm{~m}$ apart.

The sub treatment was the use of organic amendment that includes a control without organic amendment, green waste compost (from a mixture of green waste (74\%); cattle manure (24\%) and Burkina phosphate), pig manure and cattle manure. The organic amendment was applied at the recommended rate of $20 \mathrm{t} / \mathrm{ha}$. The size of sub plots was $12 \times 9 \mathrm{~m}$. The blocks were separated by an alley of $1,5 \mathrm{~m}$.

\subsection{Plant Material}

Tomato (Lycopersicon esculentum) was used as plant material for our experiment. The variety used was F1 Mongal, which is rainfed, matures in 130 days and has average yields ranging between 40 and 50 tons per hectare. It is tolerant to tomato virus (TYLCV), Fusarium sp., Stemphylium sp., nematodes and Pseudomonas sp. [9]. This tomato variety is highly recommended, especially for rain-fed cultivation and first varietal choice, for most farmers in Burkina Faso.

\subsection{Macrofauna Sampling}

Monolith sampling of soil macrofauna was done according to the standard TSBF

Table 1. Characteristics of the soil $(0-20 \mathrm{~cm})$ and organic amendments.

\begin{tabular}{cccccccccc}
\hline & Clay & Silt & Sand & $\mathrm{Ct}$ & $\mathrm{Nt}$ & $\mathrm{C} / \mathrm{N}$ & $\mathrm{Kt}$ & $\mathrm{Pt}$ & $\mathrm{pHw}$ \\
\cline { 2 - 9 } & & & & & $\mathrm{g} \cdot \mathrm{kg}^{-1}$ & \multicolumn{3}{c}{$\mathrm{mg} \cdot \mathrm{kg}^{-1}$} \\
Soil & 14.42 & 24.76 & 60.82 & 007.30 & 00.45 & 16.22 & 1088.5 & 936.1 & 06.18 \\
Cattle manure & - & - & - & 411.20 & 24.80 & 16.54 & 10250.0 & 8210.0 & 07.96 \\
Compost & - & - & - & 210.00 & 13.20 & 16.41 & 6220.0 & 19787.9 & 08.32 \\
\hline
\end{tabular}


method [10]. Sampling was conducted in May 2013, 8 weeks after crop planting according to the standard method TSBF. One soil monolith of $25 \mathrm{~cm} \times 25 \mathrm{~cm} \times$ $30 \mathrm{~cm}$ depth was randomly excavated in each replicate plot using shovel. Termites and other group of macrofauna were kept in $75 \%$ alcohol and earthworms in $75 \%$ alcohol $+4 \%$ formaldehyde before being transported in sealed vials to the laboratory for identification and inventory [11]. Earthworm and termite parameters, including abundance (numbers of individuals per $\mathrm{m}^{2}$ ) and taxonomic richness were calculated. Taxonomic richness (S) was calculated as the number of taxa per monolith [12].

\subsection{Soil Sampling}

Composite soil samples from five spots at $0-20 \mathrm{~cm}$ were taken from each plot after crop harvest using an auger. Samples were sieved through $2 \mathrm{~mm}$ mesh for chemical and physical parameters determinations.

\subsection{Data Analysis}

Analysis of variance (ANOVA) was performed using a General Linear Model (GLM) implemented in Genstat Discovery Edition 4 statistical software for Windows. Differences were significant at $\mathrm{p}<0.05$ according to Tukey's tests. Species diversity was expressed using Shannon index $H^{\prime}=-\sum(p i \ln p i)$, where $H^{\prime}$ : Shannon diversity index; pi: the proportion of individuals that are taxon relative to all individuals from all taxa collected. Shannon diversity index was calculated as: $\mathrm{p}(\mathrm{i})=\mathrm{ni} / \mathrm{N}$; where $\mathrm{ni}$ is the number of individuals for species $\mathrm{i}$ and $\mathrm{N}$ is the total number (individuals of all species). Evenness (E) was calculated as: $I E=H^{\prime} / \ln S$ [12]; where $S$ is the richness of macrofauna community.

\section{Results}

\subsection{Effects of Pesticides on Earthworms in the Presence of Organic Amendments}

A total of 267 earthworms belonging to Acanthodrilidae family were collected. It was Millsonia inermis and Dichogaster affinis. Dichogaster affinis, a shallow species that feeds the soil from the horizon $0-10 \mathrm{~cm}$ dominated in the experiment ( $82 \%$ of the total density of earthworms). Millsonia inermis ( $18 \%$ of the total density of earthworms) live at $30-40 \mathrm{~cm}$ depth but come to the soil surface to feeds on the organic fraction.

The results showed that without organic amendment, the presence of lambda super (lambda-cyhalothrin) led to a total disappearance of earthworms. Under the same conditions, the earthworm population remained stable in the presence of Dursban (chlorpyrifos ethyl) compare to the control ( 5 individuals $/ \mathrm{m}^{2}$ ). However, the effect of both pesticides was not significant.

Table 2 shows that the earthworms' population increased in the presence of the organic amendments (compost, pig manure and cattle manure). However, only the treatment with cattle manure and Dursban (91 individuals $/ \mathrm{m}^{2}$ ), signifi- 
cantly increased earthworm population compared to other treatments (0 - 42 individuals $/ \mathrm{m}^{2}$ ). The Evenness (E) shows that treatment with compost + Dursban $(\mathrm{E}=0.99)$ had the best earthworms distribution (Table 2). Shannon indices show a diversity of earthworms after treatment in the following decreasing order: M1P2 (IS = 0.689), M3P2 (IS = 0.368) and M1P1 (IS = 0.364). Relative to the average value of the Shannon index (0.118), only M1P2 (0.689), M3P2 (0.368) M1P1 (0.364) treatments had a higher than average diversity (Table 2). These results showed that the compost increased the diversity of earthworms in the soil in the presence of both pesticides.

\subsection{Effects of Pesticides on Termites in the Presence of Organic Amendments}

In this study, 939 individuals of termites were collected represented by Odontotermes sp. belong to the mushroom family and Trinervitermes sp, from reapers family. Dursban and Lamba super increased the density of termites to 21 individuals $/ \mathrm{m}^{2}$ and 16 individuals $/ \mathrm{m}^{2}$ respectively compared to the control without pesticides (0 individuals $/ \mathrm{m}^{2}$ ) (Table 3$)$. With organic amendment, Dursban and Lambda super did not have significant effect on termites. The results have shown that cattle manure $\left(11\right.$ individuals $\left./ \mathrm{m}^{2}\right)$ and compost $\left(0\right.$ individuals $\left./ \mathrm{m}^{2}\right)$ in the presence of Lambda super, have decreased the density of termites compared to the control $\left(16\right.$ individuals $\left./ \mathrm{m}^{2}\right)$. However, pig manure + Lambda super (85 individuals $/ \mathrm{m}^{2}$ ) have stimulated termites' population. In the presence Dursban, compost $\left(256\right.$ individuals $\left./ \mathrm{m}^{2}\right)$ and pig manure $\left(298\right.$ individuals $/ \mathrm{m}^{2}$ ) have significantly stimulated the termites' population compared to the control without or-

Table 2. Density of earthworms in each treatment of experiment.

\begin{tabular}{|c|c|c|c|c|c|}
\hline Treatments & Species & Number $/ \mathrm{m}^{2}$ & $\begin{array}{l}\text { Total density } \\
\text { (individual } / \mathrm{m}^{2} \text { ) }\end{array}$ & IS & $\mathrm{E}$ \\
\hline MOP0 & Dichogaster affinis & 05 & $05 a \pm 9.23$ & 0.000 & 0.000 \\
\hline M0P1 & - & 00 & $00 \mathrm{a} \pm 0,00$ & 0.000 & 0.000 \\
\hline M0P2 & Dichogaster affinis & 05 & $05 a \pm 9.23$ & 0.000 & 0.000 \\
\hline M1P0 & Dichogaster affinis & 21 & $21 \mathrm{a} \pm 9.23$ & 0.000 & 0.000 \\
\hline M1P1 & $\begin{array}{l}\text { Dichogaster affinis } \\
\text { Millsonia inermis }\end{array}$ & $\begin{array}{l}37 \\
05\end{array}$ & $42 \mathrm{a} \pm 18.47$ & 0.364 & 0.520 \\
\hline M1P2 & $\begin{array}{l}\text { Dichogaster affinis } \\
\text { Millsonia inermis }\end{array}$ & $\begin{array}{l}05 \\
06\end{array}$ & $11 \mathrm{a} \pm 9.23$ & 0.689 & 0.990 \\
\hline M2P0 & Dichogaster affinis & 05 & $05 \mathrm{a} \pm 9.23$ & 0.000 & 0.000 \\
\hline $\mathrm{M} 2 \mathrm{P} 1$ & Dichogaster affinis & 11 & $11 \mathrm{a} \pm 9.23$ & 0.000 & 0.000 \\
\hline $\mathrm{M} 2 \mathrm{P} 2$ & Dichogaster affinis & 37 & $37 \mathrm{a} \pm 18.47$ & 0.000 & 0.000 \\
\hline M3P0 & Dichogaster affinis & 11 & $11 \mathrm{a} \pm 9.23$ & 0.000 & 0.000 \\
\hline M3P1 & Dichogaster affinis & 27 & $27 \mathrm{a} \pm 9.23$ & 0.000 & 0.000 \\
\hline M3P2 & $\begin{array}{l}\text { Dichogaster affinis } \\
\text { Millsonia inermis }\end{array}$ & $\begin{array}{l}80 \\
11\end{array}$ & $91 b \pm 15.30$ & 0.368 & 0.530 \\
\hline
\end{tabular}

M0: Control without organic amendment; M1: compost; M2: Pig manure; M3: Cattle manure; P0: Control without pesticide P1: Lambda super P2: Dursban In a same column, values affected with the same letter are not significantly different at $\mathrm{p}<5 \%$. 
Table 3. Density of termites by pesticides and organic amendment applied.

\begin{tabular}{|c|c|c|c|c|c|}
\hline Treatments & Species & Number $/ \mathrm{m}^{2}$ & $\begin{array}{l}\text { Density of termites } \\
\text { (individual } / \mathrm{m}^{2} \text { ) }\end{array}$ & IS & $\mathrm{E}$ \\
\hline M0P0 & - & 000 & 000a & 0.000 & 0.000 \\
\hline M0P1 & Odontotermes sp. & 016 & $016 a$ & 0.000 & 0.000 \\
\hline M0P2 & Trinervitermes sp. & 021 & $021 \mathrm{a}$ & 0.000 & 0.000 \\
\hline M1P0 & Trinervitermes sp. & 139 & $139 a$ & 0.000 & 0.000 \\
\hline M1P1 & - & 000 & 000a & 0.000 & 0.000 \\
\hline M1P2 & $\begin{array}{l}\text { Trinervitermes sp. } \\
\text { Odontotermes sp. }\end{array}$ & $\begin{array}{l}101 \\
155\end{array}$ & $256 a$ & 0.670 & 0.960 \\
\hline $\mathrm{M} 2 \mathrm{P} 0$ & - & 000 & $000 \mathrm{a}$ & 0.000 & 0.000 \\
\hline $\mathrm{M} 2 \mathrm{P} 1$ & Trinervitermes sp. & 085 & 085 & 0.000 & 0.000 \\
\hline $\mathrm{M} 2 \mathrm{P} 2$ & $\begin{array}{l}\text { Odontotermes sp. } \\
\text { Trinervitermes sp. }\end{array}$ & $\begin{array}{l}213 \\
085\end{array}$ & $298 \mathrm{a}$ & 0.357 & 0.515 \\
\hline M3P0 & $\begin{array}{l}\text { Odontotermes sp. } \\
\text { Trinervitermes sp. }\end{array}$ & $\begin{array}{l}075 \\
028\end{array}$ & $103 a$ & 0.354 & 0.510 \\
\hline M3P1 & Odontotermes sp. & 011 & $011 \mathrm{a}$ & 0.000 & 0.000 \\
\hline M3P2 & Trinervitermes sp. & 011 & $011 \mathrm{a}$ & 0.000 & 0.000 \\
\hline
\end{tabular}

M0: Control without organic amendment M1: compost M2: Pig manure M3: Cattle manure P0: Control without pesticide P1: lambda super P2: Dursban In a same column, values affected with the same letter are not significantly different at $\mathrm{p}<5 \%$.

ganic amendment + Dursban $\left(21\right.$ individuals $\left./ \mathrm{m}^{2}\right)$. The best Evenness was obtained with Dursban + compost treatment $(E=0.96)$. The highest termites diversity was observed with pig manure and Dursban treatment $(\mathrm{M} 2 \mathrm{P} 2$, IS = $0.357)$ and compost with Dursban $(\mathrm{M} 1 \mathrm{P} 2$, IS $=0.670)$ and cattle manure without pesticide (M3P0, IS $=0.354)$. Relative to the average value of the Shannon index (0.128), only M2P2, M1P2 M3P0 had a higher diversity than average (Table 3).

\subsection{Effects of Pesticides on the Density of Various Groups of Macrofauna in the Presence of Organic Amendments}

The inventory has raised 501 individuals belonging to groups other than termites and earthworms. These macrofauna groups were represented in 7 orders that are Ants, Coleoptera, Hemiptera, Collembola, Myriapoda, Arachnida and Diptera (Table 4).

Table 4 shows that Lambda super have increased these macrofauna groups (27 individuals $/ \mathrm{m}^{2}$ ) but Dursban has decreased (5 individuals $/ \mathrm{m}^{2}$ ) compared to the control $\left(16\right.$ individuals $\left./ \mathrm{m}^{2}\right)$.

Compared to their respective control without organic amendment (26.66 for Lambda super and 5.33 for Dursban), Lambda super (32 - 75 individuals $/ \mathrm{m}^{2}$ ) and Dursban (22 - 52 individuals $/ \mathrm{m}^{2}$ ) have increased the density of the groups in the presence of organic amendments. With both pesticides, the trend of the evolution of these groups of macrofauna was: M2 $>$ M3 $>$ M1. 
Table 4. Effect of pesticides on various groups of macrofauna in the presence of organic amendment.

\begin{tabular}{|c|c|c|c|}
\hline Treatments & Groups & Individuals $/ \mathrm{m}^{2}$ & Total number \\
\hline \multirow{2}{*}{ M0P0 } & Ants & 11 & \multirow{2}{*}{$16 \mathrm{ab}$} \\
\hline & Coleoptera & 05 & \\
\hline \multirow{4}{*}{ M1P0 } & Coleoptera & 32 & \multirow{4}{*}{$47 \mathrm{ab}$} \\
\hline & Hemiptera & 05 & \\
\hline & Ants & 05 & \\
\hline & Collembola & 05 & \\
\hline \multirow{3}{*}{$\mathrm{M} 2 \mathrm{P} 0$} & Coleoptera & 38 & \multirow{3}{*}{$75 b$} \\
\hline & Myriapoda & 05 & \\
\hline & Ants & 32 & \\
\hline \multirow{3}{*}{ M3P0 } & Ants & 32 & \multirow{3}{*}{$48 \mathrm{ab}$} \\
\hline & Coleoptera & 11 & \\
\hline & Myriapoda & 05 & \\
\hline \multirow{3}{*}{ M0P1 } & Coleoptera & 11 & \multirow{3}{*}{$27 \mathrm{ab}$} \\
\hline & Arachnida & 05 & \\
\hline & Ants & 11 & \\
\hline \multirow{2}{*}{ M1P1 } & Coleoptera & 27 & \multirow{2}{*}{$32 \mathrm{ab}$} \\
\hline & Arachnida & 05 & \\
\hline \multirow{4}{*}{ M2P1 } & Coleoptera & 27 & \multirow{4}{*}{$75 b$} \\
\hline & Ants & 32 & \\
\hline & Arachnida & 11 & \\
\hline & Collembola & 05 & \\
\hline \multirow{2}{*}{ M3P1 } & Coleoptera & 43 & \multirow{2}{*}{$70 \mathrm{~b}$} \\
\hline & Ants & 27 & \\
\hline M0P2 & Coleoptera & 05 & $05 a$ \\
\hline \multirow{2}{*}{ M1P2 } & Ants & 17 & \multirow{2}{*}{$22 \mathrm{ab}$} \\
\hline & Diptera & 05 & \\
\hline \multirow{3}{*}{$\mathrm{M} 2 \mathrm{P} 2$} & Coleoptera & 42 & \multirow{3}{*}{$52 \mathrm{ab}$} \\
\hline & Arachnida & 05 & \\
\hline & Ants & 05 & \\
\hline \multirow{4}{*}{ M3P2 } & Arachnida & 05 & \multirow{4}{*}{$32 \mathrm{ab}$} \\
\hline & Ants & 11 & \\
\hline & Coleoptera & 11 & \\
\hline & Collembola & 05 & \\
\hline
\end{tabular}

M0: Control without organic amendment; M1: compost; M2: Pig manure; M3: Cattle manure P0: Control without pesticide; P1: lambda super; P2: Dursban In a same column, values affected with the same letter are not significantly different at $\mathrm{p}<5 \%$.

\section{Discussion}

\subsection{Effects of Pesticides on Earthworms in the Presence of Organic Amendments}

Considering the effects of pesticides on earthworms, results showed that Dursban (chlorpyrifos ethyl) and Lambda super (lambda-cyhalotrin) had no significant effect on the density of earthworms. The capacity of macrofauna to degrade pesticides and decrease their effect has been observed by many authors. Bhattacharya and Sahu [13] found that dimethoate at the recommended rate did not 
have effect on earthworm's population. Schreck [14] studied the effect of lambda-cyhalothrin, chlorpyrifos ethyl and fungicides on earthworms. The author has found very little or no pesticides bioaccumulate in their tissues organisms even for individuals exposed to the highest concentrations of pesticides during long periods. Thus, earthworms degrade pesticides in their tissues. Gaw et al. [15] argued that there is an incorporation and degradation of pp, DDE molecules by earthworms. However pesticide degradation by earthworms has some effects on their organisms. According to Bhattacharya and Sahu [13] the chlorpyrifos ethyl and dimethoate have negative effects on the growth, reproduction and metabolism of earthworms. Interaction between organic amendments and pesticides has significantly increased the density of earthworms in our study. This could be explained by the presence of easily degradable organic matter due to stimulation of organic amendment degradation by pesticides. In fact, according to Zida [16] the abundance of earthworms is related to the presence of easily degradable organic matter. Under certain conditions, pesticides can stimulate the degradation of organic amendment by activating soil microorganisms and produce some easily degradable organic matter. Pesticides can be degraded in this case by cometabolism [17].

\subsection{Effects of Pesticides on Termites in the Presence of Organic Amendments}

Termites were represented by Odontotermes sp., a mushroom grower cultivating their fungi in soils galleries, and Trinervitermes sp., a reaper feeding on litter. Pesticides have stimulated the density of termites in the soil. In fact, the mode of action and toxicity of pesticides are not only based on the nature of the product and the dose used, but also the group of targeted individuals and the stage of growth. Parvathi et al. [18] showed that the locomotion function and acetylcholinesterase activity of Odontotermes obesus treated with chlorpyrifos ethyl and monocrotophos (organophosphates) are not disturbed in the same way. They have demonstrated a high sensitivity to chlorpyrifos ethyl by Odontotermes $o b$ esus, which contradicts our results. With both pesticides (Dursban and Lambda super), cattle manure have decreased the density of termites. This could be explained by a decrease of the quantity of recalcitrant organic amendment. Pesticides have probably stimulated the degradation of lignin and cellulose contained in the cattle manure which led to development of earthworms as stated by Zida et al. [16] that earthworms are more competitive than termites in soils containing easily degradable organic matter.

The chlorpyrifos ethyl and compost treatment had the best index of diversity and evenness of earthworms and termites. This shows that the compost is most favorable to the balanced and diversified development of earthworms and termites. Our results confirm those of Ouédraogo [19] which showed a better index of diversity and evenness of soil macrofauna in the presence of compost. Also, Tejada et al. [20] showed that chlorpyrifos ethyl was adsorbed by organic matter preferentially on the humic acids, which makes them less toxic. This confirms 
the stimulator role of soil macrofauna by organic amendments showed by Traoré et al. [21].

\subsection{Effects of Pesticides on Groups Other than Earthworms and Termites in the Presence of Organic Amendments}

Our results showed a decrease of the number of Ants, Coleoptera, Hemiptera, Collembola, Myriapoda, Arachnida and Diptera in the presence of chlorpyrifos ethyl. These results are similar to those of Endlwerber et al. [22] who reported that the chlorpyrifos ethyl causes a decrease in population density of Collembola. The authors explained this by the fact that the chlorpyrifos ethyl had not affected the predators of this group, thereby resulting in competition and a reduction of the population of Collembola. Chlorpyrifosethyl has a half-life time of 0 - 7 days [23], short enough to be degraded at the time of the inventory of macrofauna which occurred 15 days after the date of the last pesticide treatment. According to Robertson et al. [24], the degradation of chlorpyrifos ethyl is very fast in soil and is more related to abiotic factors than biological. This result is also explained by the presence of highly toxic degradation products for this group of macrofauna. Racke et al. [4] reported that chlorpyrifos-ethyl is degraded to 3, 5, 6 pridinol esticirichloro-2-pyde (TCP). The effect of pesticides on these macrofauna groups would be due to the pesticide degradation products, which are sometimes more toxic than the parent compound [25]. In the same conditions there was an increase in the density of these groups in the presence of lambda-cyhalothrin. Stimulation of microbial activity by lambda-cyhalothrin could explain our results.

With both pesticides, the trend of the evolution of other groups of macrofauna is: M2 > M3 > M1. This evolutionary trend is the same as the $\mathrm{C} / \mathrm{N}$ ratio of organic amendments. Organic amendments with a $\mathrm{C} / \mathrm{N}$ ratio are those indicated for reducing the effects of pesticides on macrofauna groups other than termites and earthworms. This will allow a good availability of nutrients for plants and also better performance. Ouédraogo et al. [26] conducted a study on the impact of soil macrofauna and soil management on some properties of soil and yields. The results revealed that the interaction between the organic amendment with high $\mathrm{C} / \mathrm{N}$ and soil macrofauna significantly increased the yield of grain sorghum by $385 \%$.

\section{Conclusions}

The objective of this study was to evaluate the effects of pesticides on soil macrofauna in the presence of organic amendments. The results showed that the effect of lambda-cyhalothrin and chlorpyrifos ethyl on soil macrofauna depends on the nature of the pesticide and macrofauna group. Both pesticides have boosted the density of termites, but only chlorpyrifos ethyl had led to a decline in the density of macrofauna groups other than termites and earthworms. From our results, we can conclude that organic amendments helped reduce the effects of lambda-cyhalothrin on soil termite and other group of macrofauna. The same effect was observed with chlorpyrifos ethyl, except termites in the presence of 
cattle manure.

The use of organic amendments should always be recommended; however, appropriated pesticide should be chosen to avoid their impacts on soil organisms. For ecological agriculture, the use of lambda-cyhalothrin should be encouraged because its effects are quickly neutralized by organic amendment. Our results mean also that organic amendment and earthworms could be used for soil depollution.

\section{Acknowledgements}

This work was financed by International Foundation for Science (IFS) through grant number C/5002-1 awarded to the first author.

\section{References}

[1] IFDC (2007) Problématique de l'utilisation des produits phytosanitaires en conservation des denrées alimentaires et en maraîchage urbain et péri urbain au Burkina Faso: Cas de Bobo Dioulasso. Ouahigouya et Ouagadougou, 51 p.

[2] Schreinemachers, P. and Tipraqsa, P. (2012) Agricultural Pesticides and Land Use Intensification in High, Middle and Low Income Countries. Food Policy, 37, 616-626. https://doi.org/10.1016/j.foodpol.2012.06.003

[3] Racke, K.D. (1993) Environmental Fate of Chlorpyrifos.

[4] Racke, K.D., Coats, J.R. and Titus, K.R. (1988) Degradation of Chlorpyrifos and Its Hydrolysis Products, 3,5,6-Trichloro-2-Pyridinol, in Soil. Journal of Environmental Science and Health Part B, 23, 527-539. https://doi.org/10.1080/03601238809372624

[5] Förster, B., Garcia, M., Francimari, O. and Römbke, J. (2006) Effects of Carbendazim and Lambda-Cyhalothrin on Soil Invertebrates and Leaf Litter Decomposition in Semi-Field and Field Tests under Tropical Conditions (Amazônia, Brazil). European Journal of Soil Biology, 42, 171-179. https://doi.org/10.1016/j.ejsobi.2006.07.011

[6] Ouédraogo, E., Mando, A. and Brussaard, L. (2004) Soil Macrofaunal-Mediated Organic Resource Disappearance in Semi-Arid West Africa. Applied Soil Ecology, 27, 259-267. https://doi.org/10.1016/j.apsoil.2004.03.003

[7] Traore, M., Lompo, F., AYUKE, F., Ouattara, B., Ouattara, K. and Sedogo, M. (2012) Influence des pratiques agricoles sur la macrofaune du sol: Cas de l'enfouissement de la paille et du fumier. International Journal of Biology and Chemistry Sciences, 6, 1761-1773. https://doi.org/10.4314/ijbcs.v6i4.31

[8] Kaloga, B. (1969) Etude pédologique de la Haute volta, région centre-sud. Rapport ORSTOM, $247 \mathrm{p}$.

[9] Tropicasem (2001) Guide mensuel, variétés recommandées pour les semis. 2 p.

[10] Anderson, J.M. and Ingram, J.S.I. (1993) Tropical Soil Biology and Fertility. A Handbook of Methods, 2nd Edition, CAB International, Wallingford, $221 \mathrm{p}$.

[11] Bignell, D.E., Constantino, R., Csuzdi, C., Karyanto, A., Konate, S., Louzada, J., Susilo, F.X., Tondoh, J.E. and Zanetti, R. (2008) Macrofauna. In: Moreira, F.M.S., Huising, J.E. and Bignell, D., Eds., A Handbook of Tropical Soil Biology: Sampling and Characterization of Below-Ground Biodiversity, Earthscan Publishers, Aldershot, 43-83.

[12] Magurran, A.E. (2006) Measuring Biological Diversity. Blackwell Publishing, Molden, $256 \mathrm{p}$. 
[13] Bhattacharya, A. and Sahu, S.K. (2013) Acute Toxicity of Dimethoate on Soil Health: A Study of Its Impact on Earthworm. International Journal of Biosciences, 3, 98-106. https://doi.org/10.12692/ijb/3.7.98-106

[14] Schreck, E. (2008) Influence des modes d'entretien du sol en milieu viticole sur le transfert des pesticides vers les eaux d'infiltration-Impact sur les lombriciens. Thèse de Doctorat de l'Université Toulouse III-Paul Sabatier, $300 \mathrm{p}$.

[15] Gaw, S., Northcott, G., Kim, N., Wilkins, A. and Jensen, J. (2012) Comparison of Earthworm and Chemical Assays of the Bioavailability of Aged 1, 1-Dichloro-2, 2-Bis (Pchlorophenyl) Ethylene, 1, 1, 1-Trichloro-2, 2-Bis (P-Chlorophenyl) Ethane, and Heavy Metals in Orchard Soils. Environmental Toxicology and Chemistry, 31, 1306-1316.

[16] Zida, Z., Ouédraogo, E., Mando, A. and Stroosnijder, L. (2011) Termite and Earthworm Abundance and Taxonomic Richness under Long-Term Conservation Soil Management in Saria, Burkina Faso, West Africa. Applied Soil Ecology, 51, 122129. https://doi.org/10.1016/j.apsoil.2011.09.001

[17] Coppola, L., Castillob, M. and Vischettia, C. (2011) Degradation of Isoproturon and Bentazone in Peat- And Compost-Based Biomixtures. Pest Management Science, 67, 107-113. https://doi.org/10.1002/ps.2040

[18] Parvathi, K., Venkateswara, J.R., Kavitha, P., Jakka, N.M. and Pallela, R. (2005) Effect of Acetylcholinesterase, Chlorpyrifos and Monocrotophos on Locomotor Behaviour and Activity of Subterranean Termites, Odontotermes obesus. Pest Management Science, 61, 417-421. https://doi.org/10.1002/ps.986

[19] Ouédraogo, J. (2015) Impacts de la macrofaune et de modes de gestion de la fertilité des sols sur quelques propriétés du sol et le rendement des cultures en zone semi-aride. Université Polytechnique de Bobo Dioulasso.

[20] Tejada, M. and Gomez, I. (2011) Use of Organic Amendments as a Bioremediation Strategy to Reduce the Bioavailability of Chlorpyrifos Insecticide in Soils. Effects on Soil Biology. Ecotoxicology and Environmental Safety, 74, 2075-2081. https://doi.org/10.1016/j.ecoenv.2011.07.005

[21] Traoré, H., Héma, S.A.O. and Traoré, K. (2014) Bt Cotton in Burkina Faso Demonstrates that Political Will Is Key for Biotechnology to Benefit Commercial Agriculture in Africa.

[22] Endlweber, K., Schadler, M. and Scheu, S. (2006) Effects of Foliar and Soil Insecticide Applications on the Collembolan Community of an Early Set-Aside Arable Field. Applied Soil Ecology, 31, 136-146. https://doi.org/10.1016/j.apsoil.2005.03.004

[23] Gupta, S., Gajbhiye, V.T., Rakesh, K.S. and Gupta, R.K. (2011) Dissipation of Cypermethrin, Chlorpyriphos, and Profenofos in Tomato Fruits and Soil Following Application of Pre-Mix Formulations. Environmental Monitoring and Assessment, 174, 337-345. https://doi.org/10.1007/s10661-010-1461-0

[24] Robertson, L.N., Chandler, K.J., Stickley, B.D.A., Cocco, R.F. and Ahmetagic, M. (1998) Enhanced Microbial Degradation Implicated in Rapid Loss of Chlorpyrifos from the Controlled Release Formulation suSucon(R) Blue in Soil. Crop Protection, 17, 29-33. https://doi.org/10.1016/S0261-2194(98)80009-4

[25] Bajwa, U. and Sandhu, K.S. (2014) Effect of Handling and Processing on Pesticide Residues in Food-A Review. Journal of Food Science and Technology, 52, 201-220. https://doi.org/10.1007/s13197-011-0499-5

[26] Ouédraogo, J., Ouédraogo, E. and Nacro, H.B. (2014) Effet de l'interaction entre des modes de gestion de fertilité et la macrofaune sur la productivité du niébé et du sorgho en zone nord soudanienne du Burkina Faso. International Journal of Biology and Chemistry Sciences, 8, 104-114. https://doi.org/10.4314/ijbcs.v8i1.10 
Submit or recommend next manuscript to SCIRP and we will provide best service for you:

Accepting pre-submission inquiries through Email, Facebook, LinkedIn, Twitter, etc. A wide selection of journals (inclusive of 9 subjects, more than 200 journals)

Providing 24-hour high-quality service

User-friendly online submission system

Fair and swift peer-review system

Efficient typesetting and proofreading procedure

Display of the result of downloads and visits, as well as the number of cited articles Maximum dissemination of your research work

Submit your manuscript at: http://papersubmission.scirp.org/

Or contact gep@scirp.org 